\title{
Hormone Synchronization and Artificial Insemination as Breeding Efforts of Philemon buceroides to Prevent their Extinction
}

\author{
M. Yamin* \\ Biology Education Study Program, Faculty of Teacher Training and Education, University of \\ Mataram, Indonesia
}

\author{
Article History \\ Received : August $11^{\text {th }}, 2021$ \\ Revised : August $29^{\text {th }}, 2021$ \\ Accepted : September $08^{\text {th }}, 2021$ \\ Published : September, $20^{\text {th }}, 2021$ \\ *Corresponding Author: \\ M. Yamin, \\ Biology Education Study Program, \\ Faculty of Teacher Training and \\ Education, University of Mataram, \\ Indonesia \\ Email: \\ muhammadyamin.fkip@gmail.com
}

\begin{abstract}
Philemon buceroides is a bird that is very difficult to breed in captivity. This paper escribes the breeding efforts that have been carried out. The aims of the study are for knowing how to breed it in captivity and as a suggestion for conservation efforts in-situ and exsitu. Efforts of breeding Philemon buceroides are conducted by supplying the Pregnant Mare Serum Godadotrophin (PMSG) hormone and the Estrogen hormone and artificial insemination for birds that are sexually mature at least one year old and physically healthy. The sample of Philemon buceroides in this study is birds that have been reared for at least 1 year to reduce stress. The sample of Philemon buceroides were acclimatized for 7 days in each bird cage according to the group. On the following day, the treatment group was superovulated to obtain more eggs than normal using PMSG hormone at a dose of 150 $\mathrm{I} \mu$ in 10 milli liters of ferologic $\mathrm{Nacl} / \mathrm{Kg} \mathrm{BW}$ once a day for three consecutive days. The control group was only given 10 milli liters of ferologic $\mathrm{NaCl}$ orally. The next day, synchronization of lust / Esterus was conducted using the Estrogen hormone at a dose of $150 \mathrm{I} \mu$ in 10 milli liters of ferological $\mathrm{NaCl}$ orally once a day for three consecutive days. For male Philemon buceroides, sperm was collected. As a result, synchronization of the reproductive hormones of Pregnant Mare Serum Gonadotrophin (PMSG) and Estrogen to male and female Philemon buceroides greatly influenced the increase in ovulation of Philemon buceroides, however the eggs produced by the mother Philemon buceroides have not yet produced chicks. In addition, it is difficult to obtain the male sperm. From the three males, only one sperm pull out only 1 drop, the other two did not pull out any sperm.
\end{abstract}

Keywords: Hormone, Breeding, Philemon buceroides

\section{Pendahuluan}

Burung koak kao (Philemon buceroides) merupakan salah satu jenis burung yang dilindungi berdasarkan UU-RI No.5 tahun 1990 dan SK Menteri Kehutanan No. 301/KptsII/1991. Perlindungan terhadap burung itu dilakukan karena penyebarannya terbatas, memiliki nilai ekonomi tinggi, peran ekologis yang penting, informasi karakteristik biologinya masih sangat sedikit, populasinya hampir punah, dan sulit berbiak di dalam penangkaran (Prana, et al., 1993; PHPA, 1988; Yamin, 2003).

Populasi Philemon buceroides di Pulau Lombok dan Sumbawa diduga hampir punah (Yamin, 2004). Menurut Laporan Sub Balai Konservasi Sumber Daya Alam Nusa Tenggara Barat (1995), perburuan tanpa kendali telah memunahkan populasi alami beberapa jenis burung di Pulau Lombok dan Pulau Sumbawa yang memiliki nilai ekonomi. Di Nusa Tenggara Barat, Philemon buceroides merupakan burung yang memiliki nilai ekonomi tinggi, karena digemari banyak orang untuk dipelihara dalam sangkar. Harganya ratusan ribu sampai jutaan rupiah per ekornya. Tidak mengherankan apabila perburuan terhadap jenis burung itu meningkat, sehingga memicu penurunan populasinya secara drastis. Bila tindakan itu dibiarkan dan tidak ada studi untuk pembiakan dan upaya konservasinya, maka Philemon buceroides akan punah dalam waktu yang tidak lama.

Ancaman kepunahan Philemon buceroides semakin besar karena termasuk burung yang sulit dikembangbiakkan dalam penangkaran. Upaya penangkarannya sampai saat ini belum berhasil. Dilaporkan bahwa Philemon buceroides termasuk salah satu dari 
enam jenis burung yang sangat sulit berbiak dalam penangkaran (Prana, et al., 1993). Di penangkaran burung Taman Mini Indonesia Indah, burung tersebut baru berbiak satu kali dalam kurun waktu sembilan tahun. Ketidakberhasilan upaya penangkarannya dapat disebabkan oleh berbagai faktor, diantaranya ketidak-sesuaian kandungan dan komposisi kimia nilai gizi makanannya dalam penangkaran dengan di habitat alam, bahan sarang, ukuran sangkar yang tidak cukup untuk melakukan prilaku tertentu sebelum dan ketika kawin; seperti halnya kuda India yang harus berlari-lari seharian sebelum kawin.

Penelitian ini mempelajari khusus upaya pengembangbiakan dengan sinkronisasi hormon Pregnant Mare Serum Gonadotrophin (PMSG) dan Hormon Estrogen terhadap reproduksi Philemon buceroides di tempat penangkaran. Hasilnya diharapkan berguna bagi : Pengelola, sebagai masukan dan data dasar untuk menentukan kebijakan pengelolaan dan upaya konservasi Philemon buceroides baik secara in-situ maupun ex-situ. Masyarakat, berhasilnya konservasi sumberdaya hayati khususnya fauna burung menjamin kelangsungan penyediaan sumber daya yang dibutuhkan, menambah pendapatan, dan meningkatkan kesejahteraan masyarakat terutama yang disekitar kawasan, baik dari kunjungan wisatawan maupun pemanfaatan langsung Philemon buceroides sebagai sumber protein ataupun dari hasil penjualannya

\section{Bahan dan Metode}

Penelitian ini merupakan tahap ketiga, tahap pertama yaitu identifikasi jenis makanan; kedua analisis kandungan nilai gizi makanan; ketiga eksperimen pengembangbiakan Philemon buceroides. Identifikasi dan analisis kandungan nilai gizi makanan Philemon buceroides telah dilakukan di Laboratorium Taksonomi dan Kimia Analitik Universitas Mataram. Eksperimen pengembangbiakan dengan sinkronisasi hormon dan inseminasi buatan dilakukan di kandang penangkaran burung Gunungsari Lombok Barat. Tahapan ketiga ini dilakukan sejak Bulan Maret sampai Bulan Oktober.

Philemon buceroides yang dijadikan sampel diaklimatisasi selama 7 hari di dalam sangkar masing-masing sesuai dengan kelompoknya. Pada hari berikutnya, kelompok perlakuan disuperovulasi untuk memperoleh telur lebih banyak dari yang normal dengan menggunakan hormon PMSG dengan dosis 150 $\mathrm{I} \mu$ dalam 10 mili liter larutan Nacl ferologik/Kg BB satu kali dalam sehari selama tiga hari berturut-turut. Kelompok kontrol hanya diberikan 10 mili liter larutan $\mathrm{NaCl}$ ferologik secara oral. Hari berikutnya dilakukan sinkronisasi birahi/Esterus dengan menggunakan hormon Estrogen dengan dosis $150 \mathrm{I} \mu$ dalam 10 mili liter larutan $\mathrm{NaCl}$ ferologik secara oral satu kali sehari selama tiga hari berturu-turut.

Sinkronisasi birahi dilakukan pada semua kelompok burung baik pada jantan maupun betina. Selanjutnya burung jantan dan betina dikawinkan dalam sangkar berukuran $60 \mathrm{~cm} \mathrm{x}$ $60 \mathrm{~cm}$ x $90 \mathrm{~cm}$. Setiap sangkar diisi dengan satu pasang Philemon buceroides (jantan dan betina). Selain itu, dilakukan juga pengambilan sperma burung jantan untuk disuntikan (inseminasi buatan) pada burung betina. Setelah telur dihasilkan dan mulai dierami oleh induknya burung jantan dipisahkan. Bila diperoleh hasil (anak Philemon buceroides), selanjutnya anak burung tersebut dibina untuk dapat dilepas kembali ke habitat aslinya di alam.

\section{Hasil dan Pembahasan}

Upaya pengembangbiakan Philemon buceroides pada kegiatan penelitian ini mencakup 5 (lima) kegiatan yaitu penyediaan sangkar atau kandang, sumber pakan, tempat bermain, bahan sarang, dan penjodohan.

\section{Penyediaan Kandang Pembiakan}

Kandang pembiakan berperan penting untuk tempat mengawinkan dan pemeliharan Philemon buceroides. Oleh karena itu, kandang pembiakan harus memberikan kenyamanan bagi Philemon buceroides terutama dalam hal ketersediaan pakan, minum dan suhu lingkungan yang ideal. Pada penelitian ini pengawinan Philemon buceroides dilakukan dengan pasangan bebas, yaitu kesepuluh ekor burung itu masing-masing 5 ekor betina dan 5 ekor jantan diberikan kebebasan memilih pasangan jodohnya. Kandang pembiakan Philemon buceroides pada penelitian ini berukuran: 4 meter x 15 meter x 5,5 meter, di areal perkebunan kelapa. Kandang tersebut dilengkapi tumbuhan dan pohon-pohon yang disukai pada habitat alam burung itu seperti : mangga (Mangifera indica), nangka (Arthocarpus integra), belimbing manis (Averhoa carambola), jambu air (Eugenia sp), 
Turi (Sesbania grandiflora), pepaya (Carica pepaya), pisang (Musa paradica), jeruk (Citrus sp), ketela (Manihot utilissima), boar (Thladiantha puncata) dan kecipir (Psophocarpus tetragonolobus) seperti dapat dilihat pada gambar 1.

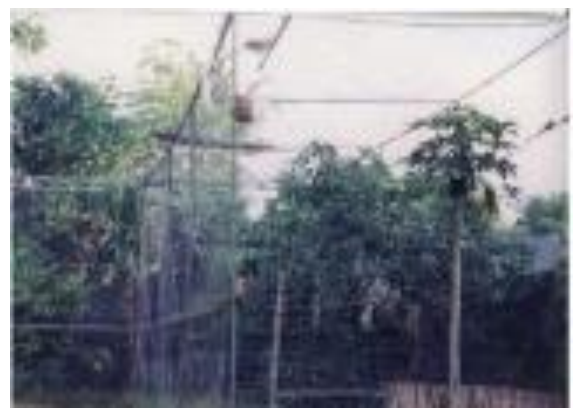

Gambar 1

Kandang pembiakan $P$. buceroides

Ukuran kandang tinggi 5,5 meter, lebar 4 meter dan panjang 15 meter. Selain itu, di dalam kandang terdapat pula berbagai tumbuhan menjalar dan rumput yang bermanfaat untuk bahan sarang. Vegetasi merupakan unsur paling penting, terutama di habitat burung, karena berfungsi sebagai sumber pakan, pelindung, dan tempat untuk berbiak (Alikodra, 1997). Selain unsur vegetasi, kandang dilengkapi juga dengan sumber air untuk minum dan air untuk mandi. Kendala yang sering terjadi pada para penangkar burung yaitu ketidak teraturannya dalam pemberian pakan dan minum begitu pula pengontrolan suhu ruangan kandang ternak, (Putra, 2012).

\section{Pengadaan Calon Induk Philemon buceroides}

Burung Philemon buceroides merupakan salah satu jenis burung yang tergolong langka. Keberadaanya di habitat alam, masyarakat maupun pasar burung sangat jarang. Semula calon induk direncanakan sebagai sampel dalam penelitian ini 5 pasang (10 ekor). Dari jumlah tersebut terdapat lima induk betina dan lima ekor induk jantan. Adapun gambaran masingmasing calon induk yang diperoleh sebagai sampel penelitian ini sebagai berikut :

Tabel 1. Kondisi Awal Fisik Induk Koak kao (Philemon buceroides) di Penangkaran

\begin{tabular}{|c|c|c|c|c|c|c|}
\hline $\begin{array}{l}\text { Sampel/I } \\
\text { nduk }\end{array}$ & Asal & $\begin{array}{l}\text { Umur } \\
\text { (Bulan) }\end{array}$ & Kelamin & $\begin{array}{c}\text { Berat } \\
\text { (Gram) }\end{array}$ & $\begin{array}{l}\text { Pemeliahraan } \\
\text { (Bulan) }\end{array}$ & $\begin{array}{c}\text { Status } \\
\text { Pemilik }\end{array}$ \\
\hline 1 & Sumbawa & 24 & B & 345 & 12 & $\mathrm{PN}$ \\
\hline 2 & Lobar & 18 & B & 315 & 8 & Polisi \\
\hline 3 & Lobar & 26 & $\mathrm{~J}$ & 370 & 12 & Polisi \\
\hline 4 & Loteng & 24 & $\mathrm{~J}$ & 355 & 16 & $?$ \\
\hline 5 & Loteng & 24 & $\mathrm{~J}$ & 340 & 10 & Swasta \\
\hline 6 & Lobar & 9 & $\mathrm{~B}$ & 298 & 8 & Swasta \\
\hline 7 & Bima & 26 & B & 356 & 10 & $?$ \\
\hline 8 & Sumbawa & 48 & $\mathrm{~J}$ & 367 & 36 & Swasta \\
\hline 9 & Lobar & 60 & B & 363 & 48 & Swasta \\
\hline 10 & Lobar & 24 & $\mathrm{~J}$ & 340 & 18 & swasta \\
\hline \multicolumn{2}{|c|}{ Rata - rata } & 28,3 & & 345 & 17,8 & \\
\hline
\end{tabular}

Dari tabel di atas terlihat umur, lama pemeliharaan, status pemilik, tingkat kesehatan, dan asal masing-masing burung tidak sama. Pemilihan calon induk seharusnya dapat dilakukan, karena akan berpengaruh terhadap keinginan kawin,penmcarianjodoh, dan kemampuan berbiak. Akan tetapi hal itu tidak dapat dilakukan karena terbatasnya ketersediaan burung itu (Philemon buceroides) di pasaran maupun di masyarakat. Adapun calon induk Philemon buceroides yang baik memiliki ciri-ciri sebagai berikut :

a. Bulu seluruh tubuh terlihat bersih, karena bulu yang kusam menunjukan burung kurang sehat. b. Pandangan mata tajam, tubuh tegap, segar, dan energik. Burung koak kao yang yang pandangan matanya sayu, penampilannya malas menunjukan burung itu kurang sehat.

c. Umur induk berkisar antara 2 (dua) sampai 3 (tiga) tahun. Burung koak kao yang berusia lebih dari lima tahun keinginan kawinnya (birahi) sudah menurun, demikian pula koak kao yang berumur kurang dari dua tahun sel kelaminnya belum berkembang sempurna (Trubus, 2004). 


\section{Pemberian Pakan}

Philemon buceroides merupakan burung sasap madu, yaitu kelompok burung pengisap madu dari suku Meliphagidae. Burung itu bersifat nektivor, frugivor, dan insectivor karena makanannya terdiri atas nektar, buahbuahan dari jenis tumbuhan tertentu dan berbagai jenis serangga. Philemon buceroides berbeda dengan anggota suku Meliphagidae lain yang memerlukan madu dan nektar setiap hari sepanjang hidupnya. Burung itu mengisap nektar hanya sewaktu-waktu terutama menjelang musim kawin. Jenis-jenis tumbuhan yang nektar bunganya disukai oleh Philemon buceroides adalah, Sterculia oblongata, Thespesia populnea, Eugenia sp., Cocos nucifera, Ceiba petandra, Bombax buonopozense dan Bombax. ceiba. Buahbuahan yang disukai yaitu buah, Saripellus asper, Thladiantha puncata, Ficus septica dan Ficus superba. Serangga yang disukai adalah Crytotympanus accuta, Oecophyla samaradigna, Kampi neurobasis, sejenis Hymenoptera, Petanga sp., dan Lepidoptera
Waktu makan $P$. buceroides dua kali sehari yaitu pagi pukul 06.00 sampai pukul 10.00 sore pukul 15 - 18.30. Dalam aktivitasnya sering berpasangan atau soliter, jarang dijumpai dalam kelompok besar (Yamin, 2004).

Pada penelitian ini pemberian pakan terhadap burung itu di kandang percobaan pembiakan disesuaikan dengan jenis makanannya seperti disebutkan di atas, yaitu makanan berupa buah-buahan dan serangga. Buah-buahan yang diberikan yaitu pepaya (Carica pepaya), pisang (Musa paradica), dan boar (Thladiantha puncata) secara bergantian. Untuk pemenuhan akan nektar $P$. buceroides diberikan bunga segar setelah dilakukan pemberian hormon PMSG. Selain itu, di dalam kandang tersedia beberpa jenis tumbuhan penghasil nektar sedang berbunga dan berbuah. seperti : Turi/kembang koak kao (Sesbania grandiflora), belimbing manis (Averhoa carambola), jambu air (Eugenia sp), Turi pepaya (Carica pepaya), pisang (Musa paradica), boar (Thladiantha puncata), dan kecipir (Psophocarpus tetragonolobus).

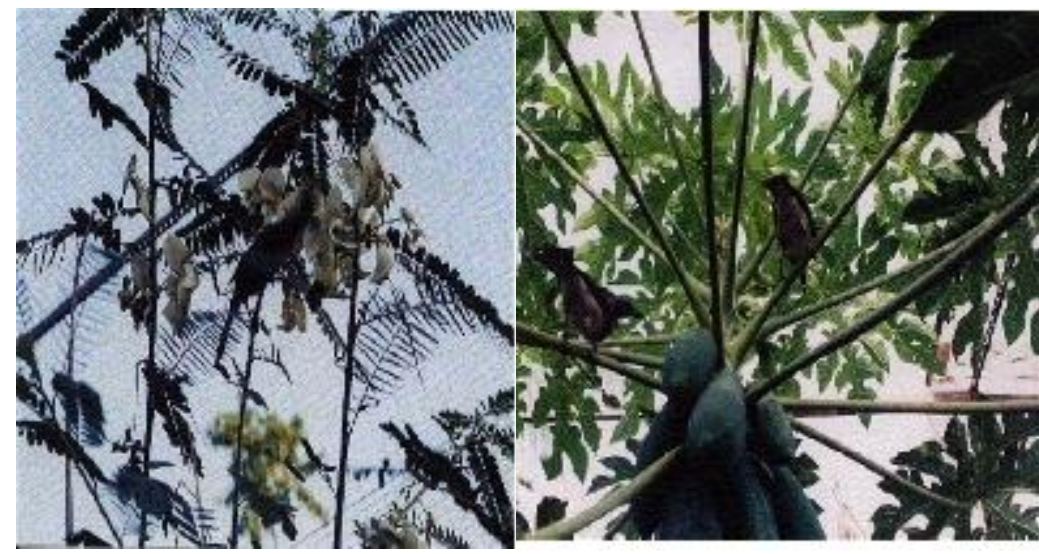

Gambar 2 Tunaman pakan $P$. buceroides di kandang penangkaran

Adapun untuk pemenuhan akan serangga, maka diberikan serangga yang dibeli dari pasar seperti : jangkrik, ulat Hongkong, dan ulat pisang satu kali seminggu. Selain itu, serannga dapat diperoleh/tangkap sendiri dari serangga yang masuk ke dalam kandang penangkaran. Adapun untuk menjaga kesehatan dan vitalitas Philemon buceroides diberikan vitamin B komplek melalui air minum yang diperoleh dari pasar dua minggu sekali.

\section{Penyediaan Sarang}

Sarang Philemon buceroides di Habitat Alam ditemui pada pohon Alstonia spectabilis, Alstonia angisteloba, dan Bombax buonopozense. Pada ketinggian antara 25 meter sampai 35 meter dari permukaan tanah dan merupakan pohon tertinggi di sekitarnya. Sarang tersebut diletakan pada sub kanopi pohon yang puncak tajuknya tidak menyatu dengan tajuk pohon lain (Yamin \& Jamaluddin, 2003). Bahan sarang Philemon buceroides sekitar $90 \%$ terbuat dari anyaman liana berdimeter rata-rata $0,3 \mathrm{~mm}$ dan panjang antara $15 \mathrm{~cm}$ sampai $100 \mathrm{~cm}$. Selain itu bahan sarangnya adalah akar paku pohon, serabut, lumut pohon, dan beberapa ranting berdiamter antara 0,2 mm-0,4 mm. Melihat jenis bahan sarangnya tersebut, dapat dipastikan burung itu tidak pernah mengambilnya dari permukaan tanah (Yamin, $d k k .$, 2004). Bentuk sarangnya oval, tinggi $\pm 13 \mathrm{~cm}$, lebar $\pm 12 \mathrm{~cm}$, diameter lubang $\pm 10 \mathrm{~cm}$, kedalaman lubang $\pm 9 \mathrm{~cm}$, dan tebal dinding antara $2,5 \mathrm{~cm}$ sampai $5 \mathrm{~cm}$. Berat 
(masa) antara 314 gram sampai dengan 330 gram, tergantung (terikat) dengan 11 sampai 17 batang liana pada 5 sampai 7 ranting berdiameter antara $5,45 \mathrm{~cm}$ sampai 23, $26 \mathrm{~cm}$.

Penyediaan sarang Koak Kao pada penelitian ini semula disediakan dari sarangnya yang diambil dari habitat alam, namun setelah ditempatkan di dalam kandang sarang tersebut dibongkar dan berusaha disusun ulang oleh $P$. buceroides tersebut. Penyusunan kembali sarang dari habitat alam oleh burung tersebut tidak berhasil karena bahannya sudah kaku, tidak dapat diikatkan pada ranting atau kayu tenggeran yang terdapat di dalam kandangnya. Untuk memenuhi kebutuhan burung itu akan sarang, peneliti melakukan modifikasi terhadap bahan, struktur, dan bentuk sarang seperti terlihat pada gambar berikut.
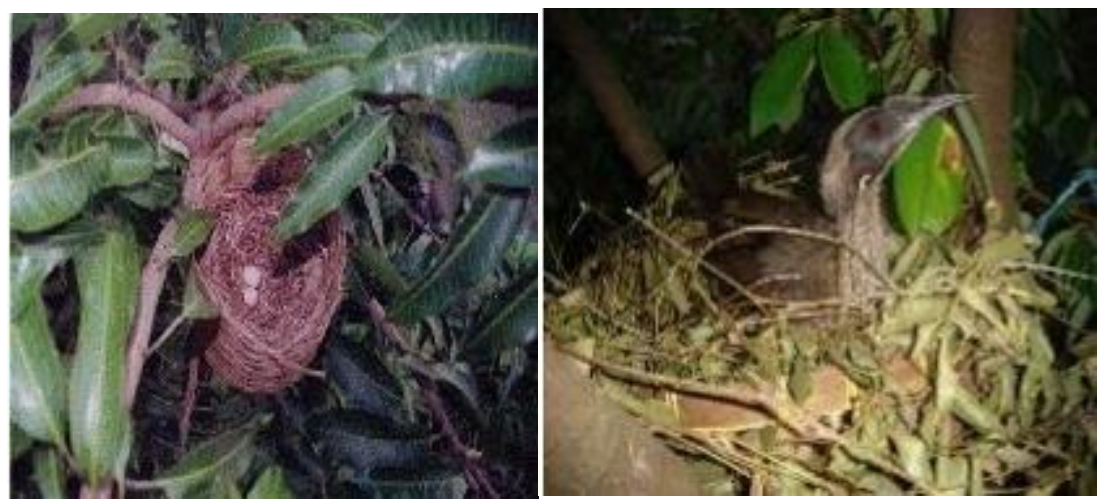

Gambar 3. Penyediaan sarang Philemon buceroides di kandang pembiakan

Sarang dibuat dalam sangkar berbentuk bundar berdiameter $25 \mathrm{~cm} \times 35 \mathrm{~cm}$ dari bahan liana, batang rumput, serabut batang pisang, dan sabut kelapa. selanjutnya sarang tersebut diletakan pada pojok atas kandang dan ranting pohon yang terdapat di dalam kandang seperti pada habitat alamnya. Dari 5 buah sarang yang disediakan baru 3 buah yang dimanfaatkan untuk bertelur. Masing-masing induk menggunakan sarang yang sama pada setiap periode bertelurnya( sampai saat ini sudah 4 periode), tidak mau pindah ke sarang lain. Sarang yang dipakai adalah sarang yang diletakan pada pojok atas kandang. Hal ini karena burung itu di alam membuat sarang di puncak tajuk pohon yang tajuknya tidak menyatu dengan tajuk pohon lain (Yamin \& Jamaluddin, 2003). Hal lain yang perlu dicatat adalah burung itu melengkapi bahan sarangnya dari berbagai jenis bahan yang terdapat di dalam kandang seperti dedaunan pisang, benag wool, dan karung goni.

\section{Penjodohan Koak kao (Philemon buceroides)}

Setelah dilakukan pemberian hormon terhadap kedua induk (jantan dan betina) burung koak kao yang dibiakan dalam penelitian ini, selanjutnya masing-masing induk burung itu dijodohkan dengan pasangan tetap, yaitu induk jantan dan betina dimasukan ke dalam satu sangkar berukuran $60 \mathrm{~cm}$ x $60 \mathrm{~cm}$ x $90 \mathrm{~cm}$. Ukuran kandang yang ideal untuk proses pelaksanaan dan keperluan IB untuk unggas merujuk Ariyaningsih (2017) adalah kandang battery secara individu. Dari lima pasang (sepuluh ekor) tersebut tidak satu pun mau kawin dengan cara itu (pasangan tetap), mereka enggan kawin, bertengkar dan berkelahi sepanjang hari. Untuk mengatasi hal tersebut, kemudian burung koka kao dijodohkan secara bebas, yaitu kedua jenis induk burung itu diberikan kebebasan memilih pasangan hidupnya. Pertama, induk koak kao (jantan dan betina) masing-masing dimasukan ke dalam sangkar berukuran $60 \mathrm{~cm}$ x $60 \mathrm{~cm}$ x $90 \mathrm{~cm}$ dan di tempatkan berdekatan selama satu minggu (tanggal 21 - 27 Maret 2005), selanjutnya di masukan ke dalam kandang berukuran 4 meter $\mathrm{x} 15$ meter x 5,5 meter untuk memilih pasangan sendiri. Koak kao yang dimasukan dan dilepas dalam kandang tersebut selama satu minggu terlihat tidak kuat terbang, enggan menggunakan pohon-pohon yang terdapat di dalam kandang, bergantung pada dinding dan atap kandang. Selin upaya pembiakan dengan perlakuan tersebut di atas, dilakukan juga upaya pembiakan dengan pengambilan sperma burung jantan untuk disuntikan (IB) pada burung betina. Faktor terpenting dari tingkat keberhasilan IB pada itik adalah kualitas dan kuantitas air mani/ sperma (Tjuk Imam Restiadi, dkk. 2019). Pengambilan sperma Philemon buceroides jantan tidak berhasil. Hal ini diduga karena burung Philemon buceroides yang menjadi sampel masih stres saat pengambilan spermanya. Berikut disajikan 
gambaran masing-masing induk Philemon buceroides yang dibiakan dalam kandang penangkran pada Tabel 2 .

Tabel 2. Gambaran induk burung koak kao yang dikawin bebas dalam kandang penangkaran

\begin{tabular}{|c|c|c|c|c|c|c|c|c|c|c|}
\hline Sampel & I & II & III & IV & $\mathrm{V}$ & VI & VII & VIII & IX & $\mathrm{X}$ \\
\hline Kelamin & $\mathrm{B}$ & $\mathrm{B}$ & $\mathbf{J}$ & $\mathbf{J}$ & $\mathrm{J}$ & $\mathrm{B}$ & $\mathrm{B}$ & $\mathrm{J}$ & $\mathrm{B}$ & $\mathrm{B}$ \\
\hline Umur & 24 & 18 & 26 & 24 & 24 & 9 & 26 & 48 & 60 & 60 \\
\hline Pemeliharaan & 12 & 8 & 12 & 16 & 10 & 8 & 10 & 36 & 48 & 48 \\
\hline Kawin & Maret & Juni & Maret & Juni & - & - & Mei & - & Sep & Sep \\
\hline Bersarang & Maret & Juni & - & - & - & - & Juni & - & - & - \\
\hline Bertelur & $6,7,8,9$ & 8,9 & - & - & - & - & $7,8,9$ & - & - & - \\
\hline$\sum$ telur/periode & $2,2,2,1,2$ & 2,2 & - & - & - & - & $2,2,2$ & - & - & - \\
\hline Pengeraman & 13- 21 & 14 & - & - & - & - & 15 & - & - & - \\
\hline Status pemilik & $\mathrm{PN}$ & POL & POL & $?$ & SWT & SWT & $?$ & SWT & SWT & SWT \\
\hline
\end{tabular}

Dari kelima pasang burung Philemon buceroides yang dimasukan ke dalam kandang pembiakan tersebut, terlihat tiga ekor betina mencari dan mengangkat bahan sarang. Dua hari kemudian seekor betina bertelur, disusul betina lainnya dua minggu kemudian. Dari 5 ekor betina telah berhasil bertelur 3 ekor, masing-masing empat, enam, dan delapan kali (periode). Jumlah telur masing-masing setiap periode 2 butir kecuali pada periode ke 3 satu butir. Pengeraman telur pada periode pertma oleh masing-masing induk antara 14 - 15 hari, periode kedua antara 19 sampai 21 hari, periode ketiga dan keempat 17 hari. Telur-telur yang dierami tersebut belum ada yang mengandung emberio (zigot) dan menghasilkan piyek (anak), karena tidak terbuahi. Telur yang dihasilkan berbentuk lonjong panjang antara $28 \mathrm{~mm}$ sampai 33,5 mm, berat antara 5, 35 gram sampai 7, 82 gram, diameter antara $22 \mathrm{~mm}$ sampai 24 , $3 \mathrm{~mm}$, dan tebal kulit cangkang $0,5 \mathrm{~mm}$. seperti terlihat pada gambar 4 di bawah ini.

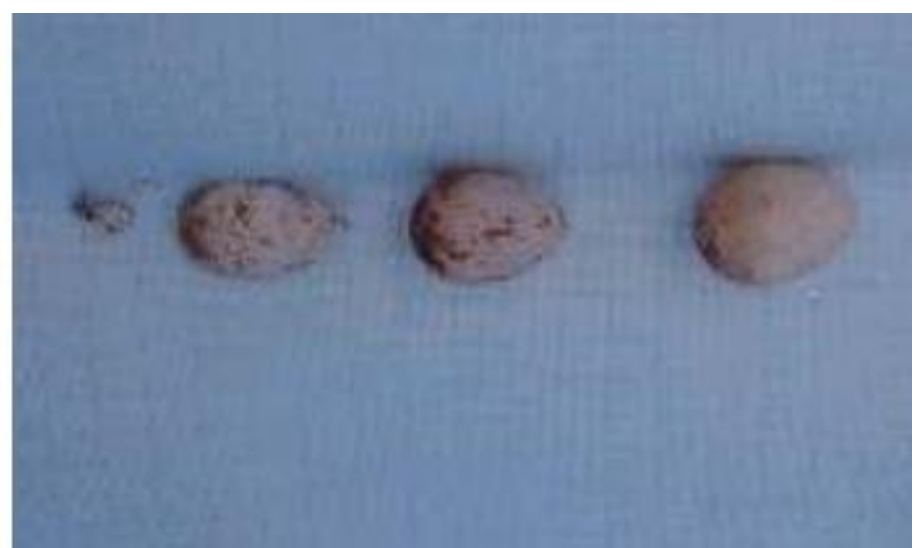

Gambar 4. Telur Philemon buceroides hasil sinkronisasi hormon PMSG dan estrogen.

Adapun dua ekor induk betina sisanya belum bertelur, nanmun sudah mulai terlihat mencari dan mengangkat bahan sarang. Dari keempat ekor pejantan terlihat dua ekor masih belum kuat terbang, diduga karena telah terlalu lama dipeliahara di dalam sangkar berukuran $60 \mathrm{~cm}$ x $60 \mathrm{~cm}$ x $90 \mathrm{~cm}$, umur terlalu tua sekitar 7 tahun sedang yang lain umurnya masih terlalu muda yaitu sekitar 8 bulan, dan gizi kurang baik. Ketidakberhasilan upaya pembiakana Philemon buceroides pada penelitian ini di duga karena 2 (dua) hal yaitu :
1) pembuahan sel telur oleh sperma belum dapat terjadi, karena ejakulasi terjadi di luar tubuh induk betina saat kopulasi. Hal ini diduga karena pepohonan terlalu rapat dan kandang penangakaran kurang tinggi (5,5 meter). Hal yang patut dikemukakan di sini adalah bahwa burung itu melakukan kopulasi di udara saat terbang. Dalam hubungannya dengan hal itu agar dapat terjadi pembuahan sel kelamin betina oleh sel kelamin jantan secara alami 
harus ada ruang yang cukup (tinggi dan panjang) untuk melakukan gerakan kopulasi. Di alam burung itu melakukan kopulasi dengan cara terbang tinggi lebih dari 15 meter (Yamin, 2003). Selain itu, menurut Widiarso (2020) kendala yang sering dialami dalam upaya pembiakan burung adalah kesiapan calon induk jantan dan betina, suasana kandang dan suhu udara sekitar.

2) Terganggunya pengeraman oleh induk. Seperti telah disebutkan di atas, bahwa semua induk Philemon buceroides baik jantan maupun betina yang dibiakan dalam penelitiani ini ditempatkan dalam satu kandang berukuran 4 meter x 15 meter x 5,5 meter secara bersamasama, sehingga induk yang sedang mengeram seringkali mendapat gangguan dari induk lain. Induk Philemon buceroides yang sedang mengeram terlihat sring keluar meninggalkan telur dalam sarangnya karena diganggu induk burung yang tidak mengeram, sehingga telur yang dieram diduga tidak mendapat pengeraman yang optimal. Akibatnya telur yang dieram tersebut tidak dapat menghasilkan anak burung Philemon buceroides. Hal ini didkukung oleh pendapat Widiarso (2020), bahwa kendala yang sering dialami dalam usaha pembiakan burung antara lain kehadiran pasangan lain dan predator seperti cecak, tikus, kadal dan semut di kandang penagkaran.

\section{Kesimpulan}

Upaya pembiakan Philemon buceroides melalui Singkronisasi hormon reproduksi Pregnant Mare Serum Gonadotrophin (PMSG) dan Estrogen terhadap induk jantan dan induk betina burung itu sangat berpengaruh terhadap peningkatan ovulasinya. Telur-telur yang dihasilkan induk Philemon buceroides pada penelitian ini, belum menghasilkan anak burung diduga karena telur-telur tersebut tidak terbuahi karena terbatasnya ruang bagi induk Philemon buceroides untuk melakukan gerakan yang diperlukan dalam perkawinan dan adanya gangguan terhadap induk Philemon buceroides yang sedang mengeram oleh pasangan Philemon buceroides yang lain di dalam kandang pembiakan. Oleh karena itu, keberadaan Philemon buceroides di alam dan masyarakat yang semakin langka dan sulit berbiak, perlu upaya pengembangbiakkan dan usaha konservasi untuk kelestariannya yang merupakan fauna khas daerah.

\section{Ucapan Terima Kasih}

Kami menyampaikanTerima Kasih kepada Direktorat Jenderal Pendidikan Tinggi, Departemen Pendidikan Nasional yang telah memberikan dana penelitian, Lemlit Universitas Mataram atas segala bantuannya dan Mahasiswa Biologi yang telah membantu di Lapangan.

\section{Referensi}

Alikodra, H. S. (1997). Pengelolaan habitat satwa liar dalam rangka mempertahankan keanekaragaman hayati. Fakultas Kehutanan IPB, Bogor.

Beehler. B.M., T.K. Pratt \& D.A. Zimmerman (1986). Birds of New Guinea. Princeton University Press, Wau, Papua New Guinea.

Borror, T \& Johnson (1992). Pengenalan pelajaran serangga. Terjemahan dari Introduction study insect, oleh Suetioyonoparto, S. Gadjah Mada University Press, Yogjakarta.

Brita Ariyaningsih (2017). Inseminasi Buatan (Artificial Insemination). Dinas Peternakan Kabupaten Lebak.

Budi Purwo Widiarso (2020). PermasalahanPermasalahan Ternak Murai Batu dan Solusinya. Bio JANNA6 Obat Alami Burung Comment.

Departemen Kehutanan, Sub BKSA (1995). Hasil survei permasalahan gangguan kawasan konservasi Taman Buru Pulau Moyo. Sub BKSDA Departemen Kehutanan, Kantor Wilayah Propinsi Nusa Tenggara Barat.

Graf, A. B. (1992). Hortica. A color cyclopedia of garden flora in all climates and indoor plants. First edition. Roehrs Company, U.S.A. 
Krebs, C. J. (1985). Ecology the experimental analysis of distribution and abundance. Third edition. Harper \& Row, London.

Muller-Dombois, D. \& H. Ellenberg (1974). Aims and methods of vegetation ecology. John Wiley \& Sons, New York.

Prana, M., E.B.Utami \& Widyabrata (1993). Program Penangkaran Burung Di Taman Mini Indonesia Indah. Burung dan Upaya Pelestariannya. Jurusan Biologi FMIPA Universitas Indonesia, Jakarta.

Rahmat Efendy (2020). Burungnya.com.

Skoog, A.D. (1985). Principles of Instrumental Analisis, Saunders College Publishing, New York.

Sudrajat (2004). Cucakrawa, Penebar swadaya, Jakarta.

Sumiarsih Emi \& Yovita Hety Indriani (1999). Melatih, memelihara, dan menangkar burung ocehan. Penebar Swadaya, Jakarta.

Tjuk Imam Restiadi, Tatik Hernawati, Dadik Rahardjo, \& Thomas V. Widiyatno.
(2019). Potensi Teknologi Inseminasi Buatan pada Peningkatan Produktivitas Itik Turi Lamongan. Ovozoa, 8(1), April 2019 ISSN: 2302-6464

Trubus (2004). Panduan praktis Sukses tangkarkan murai Batu, Niaga Swadaya, Jakarta.

Walpole, R. E. (1995). Pengantar statistik. Gramedia Pustaka Utama, Jakarta.

Yamin, M. (2003). Karakteristik habitat Koak kao (Philemon buceroides) di Taman Buru Pulau Moyo. Jurnal Biologi Tropis, 4 (1), 43-49.

Yamin, M. \& Jamaluddin (2003). Populasi dan Asosiasi Koak kao (P. buceroides) dengan Beberapa Jenis Tumbuhan pada habitatnya di Taman Buru Pulau Moyo, Nusa Tengga Barat. Jurnal Biologi Tropis, 2.

Yamin, I. Ny. Loka \& I. Wy. Mertha (2004). Studi kelangsungan hidup Koak kao $(P$. buceroides) di Taman Buru Pulau Moyo, Nusa Tengga Barat. Laporan penelitian Penguatan Riset Sains Dasar Bidang MIPA, Kementrian Riset dan Teknologi, Jakarta. 